\title{
ANALISIS FAKTOR-FAKTOR YANG MEMPENGARUHI PERMINTAAN TELEPON SELULER BERBASIS SMARTPHONE(STUDI DI GORI CELL BOJONEGORO)
}

\author{
*(Edy Suhartono \\ Fakultas Ekonomi Universitas Bojonegoro \\ edysuhartono999@gmail.com
}

\begin{abstract}
Abstrak
Penelitian ini menjelaskan hubungan antara variabel-variabel penelitian melalui pengujian hipotesa.Metode pengumpulan data penelitian ini dilakukan dengan menggunakan kuesioner.Populasi dalam penelitian ini adalah seluruh konsumen yang melakukan pembelian telepon seluler berbasis smartphone dengan kisaran harga Rp1.000.000 - Rp2.000.000 di Gori Cell.Sampel dalam penelitian ini berjumlah 80 orang.Teknik pengambilan sampel dalam penelitian ini menggunakan insidential.Berdasarkan hasil analisa data, maka hasil penelitian menunjukkan bahwa variabel promosi, brand image, dan harga berpengaruh secara simultan terhadap permintaan telepon seluler berbasis smartphone. Variabel promosi berpengaruh terhadap permintaan telepon seluler berbasis smartphone sebesar 0,303 yang artinya permintaan di tentukan variabel promosi sebesar 30,3\%. Variabel brand image berpengaruh terhadap permintaan sebesar 0,318 yang artinya permintaan ditentukan variabel brand image sebesar 31,8\%. Variabel harga berpengaruh terhadap permintaan sebesar 0,405 yang artinya permintaan di tentukan variabel harga sebesar 40,5\%. Variabel yang memiliki pengaruh dominan terhadap permintaan telepon seluler berbasis smartphone adalah harga.
\end{abstract}

Kata Kunci : promosi, brand image, smartphone

\section{PENDAHULUAN}

Kebanyakan masyarakat menyebut store retail handphone adalah gerai handphone. Salah satu contoh gerai handphone yang mengalami peningkatan jumlah pembelian telepon seluler berbasis smartphone berada di daerah kabupaten Bojonegoro yaitu Gori 1 Cell. Berikut adalah data penjualan telepon seluler berbasis smartphone pada tahun 2016 di Gori 1 Cell Bojonegoro : 


\section{Tabel 1.1}

Data penjualan telepon seluler berbasis smartphone semua harga tahun 2016

\begin{tabular}{|l|l|}
\hline Bulan & 2016 \\
\hline Januari & 1.238 \\
\hline Februari & 801 \\
\hline Maret & 1.054 \\
\hline April & 1.156 \\
\hline Mei & 1.287 \\
\hline Juni & 1.320 \\
\hline Juli & 1.433 \\
\hline Agustus & 1.489 \\
\hline September & 1.561 \\
\hline Oktober & 1.608 \\
\hline November & 1.622 \\
\hline Desember & 1.785 \\
\hline
\end{tabular}

Berdasarkan data di atas Peningkatan ini terjadi menyeluruh menunjukkan penjualan telepon seluler pada semua merek telepon seluler berbasis smartphone mengalami berbasissmartphone dari berbagai kenaikan dari bulan ke bulan selama harga.

tahun 2016 di Gori 1 Cell Bojonegoro.

\section{TINJAUAN PUSTAKA}

\section{Telepon Seluler}

Telepon genggam (telepon genggam) atau telepon seluler (ponsel) atau handphone (HP) adalah perangkat telekomunikasi elektronik yang mempunyai kemampuan dasar yang 
sama dengan telepon konvensional saluran tetap, namun dapat dibawa ke mana-mana (portabel/mobile) dan tidak perlu disambungkan dengan jaringan telepon menggunakan kabel (nirkabel wireless). Telepon pintar (smartphone) adalah telepon genggam yang mempunyai kemampuan tingkat tinggi, Kadang-kdang dengan fungsi yang menyerupai computer.Belum ada standar pabrik yang menentukan definisi telepon pintar.Bagi bebrapa orang, telepon pintar merupakan telepon yang bekerja menggunakan seluruh piranti lunak sistem operasi yang menyediakan hubungan standar dan mendasar bagi pengembang aplikasi. Bagi yang lainya, telepon pintar hanyalah merupakan sebuah telepon yang menyajikan fitur canggih seperti surel (surat elektronik), internet dan kemampuan membaca buku elektronik (e-book) atau terdapat papan ketik (baik built-in maupun eksternal) dan konektor VGA. Dengan kata lain, Telepon pintar merupakan komputer mini yang mempunyai kapabilitas sebuah telepon.

\section{Perilaku Konsumen}

Menurut Kotler dan Keller (2008:214), perilaku konsumen adalah studi bagaimana individu, kelompok dan organisasi memilih,

membeli, menggunakan dan menempatkan barang, jasa, ide atau pengalaman untuk memuaskan keinginan dan kebutuhan mereka. Sedangkan menurut Schiffman dan Kanuk (2008:6), perilaku konsumen menggambarkan cara individu mengambil keputusan untuk memanfaatkan sumber daya mereka yang tersedia (waktu, uang, usaha) guna membeli barang-barang yang berhubungan dengan konsumsi.

\section{Keputusan Pembelian}

Definisi pembelian menurut Nugroho (2003:38) adalah proses pengintegrasian yang mengkombinasi sikap pengetahuan untuk mengevaluasi dua atau lebih perilaku alternatif, dan memilih salah satu diantaranya.

Berdasarkan pendapat para ahli diatas maka dapat disampaikan bahwa keputusan pembelian adalah suatu keputusan seseorang dimana dia memilih salah satu dari beberapa alternatif pilihan yang ada dan proses integrasi yang mengkombinasi sikap pengetahuan untuk mengevaluasi dua atau lebih 
perilaku alternatif dan memilih salah satu diantaranya.

\section{Harga}

Harga adalah sejumlah uang yang dibebankan atas suatu produk atau jasa, atau jumlah dari nilai yang ditukar konsumen atas manfaatmanfaat karena memiliki atau menggunakan produk atau jasa tersebut (Kotler dan Amstrong, 2010:314)

\section{METODOLOGI PENELITIAN}

Teknik Pengambilan Sampel

1. Jenis Penelitian

Berdasarkan tujuannya, penelitian ini berjenis penelitian terapan dimana pada penelitian ini terapan, manfaat dan hasil penelitian dapat segera dirasakan oleh berbagai kalangan. Sedangkan berdasarkan jenis data dan analisisnya, penelitian ini termasuk jenis penelitian kuantitatif yaitu penelitian yang datanya merupakan data kuantitatif sehingga analisis datanya menggunakan analisis kuantitatif (inferensi).

2. Dimensi waktu penelitian
Harga merupakan elemen bauran pemasaran yang dapat menghasilkan pendapatan melalui penjualan. Oleh karena itu, perusahaan harus dapat menetapkan harga produknya dengan baik dan tepat sehingga konsumen tertarik dan mau membeli produk yang ditawarkan agar perusahaan mendapatkan keuntungan.

Penelitian ini berdasarkan dimensi waktu, di kategorikan ke dalam penelitian cross sectional atau one shot yang artinya penelitian ini dilakukan dalam satu waktu tertentu. Penelitian ini hanya digunakan dalam waktu yang ditentukan, dan tidak akan dilakukan penelitian lain di waktu yang berbeda untuk diperbandingkan. Penelitian dilakukan pada tanggal 1 mei 2017 - 31 mei 2017.

3. Metode Penelitian

Penelitian dilakukan berdasarkan metode survei, yaitu penelitian yang dilakukan pada populasi besar atau kecil 
tetapi data yang dipelajari adalah data dari sampel yang diambil dari populasi. Jika sampel yang diambil adalah

\section{Metode Analisa Data}

\section{Penentuan Variabel}

Variabel penelitian adalah suatu atribut atau sifat nilai dari orang, obyek atau kegiatan yang mempunyai variasi tertentu yang ditetapkan oleh peneliti untuk dipelajari dan kemudian ditarik kesimpulannya (Sugiyono, 2010 : 61). Penelitian ini menggunakan dua variabel, yaitu:

a. Variabel Dependen atau terikat

Variabel dependen adalah variabel yang menjadi pusat perhatian utama peneliti. Hakekat sebuah masalah mudah terlihat dengan mengenali berbagai variabel dependen yang digunakan dalam sebuah model. Variabilitis dari atau atas faktor inilah yang berusaha untuk dijelaskan oleh seorang peneliti (Ferdinand, 2006:26). Variabel dependen dinotasikan dengan Y. Dalam penelitian ini yang menjadi variabel dependen adalah keputusan pemilihan.

b. Variabel Independen atau bebas

Variabel independen merupakan variabel bebas yang dapat mempengaruhi variabel dependen representatif

maka generalisasinya kuat.

(terikat) baik yang berpengaruh positif maupun yang berpengaruh negatif (Ferdinand, 2006:26). Variabel independen dinotasikan dengan $X$. Variabel independen dalam penelitian ini adalah :
a. Harga
$\left(\mathrm{X}_{1}\right)$
b. Brand image
$\left(\mathrm{X}_{2}\right)$
c. Promosi

\subsection{Metode Analisa Data}

\section{Penentuan Variabel}

Variabel penelitian adalah suatu atribut atau sifat nilai dari orang, obyek atau kegiatan yang mempunyai variasi tertentu yang ditetapkan oleh peneliti untuk dipelajari dan kemudian ditarik kesimpulannya (Sugiyono, 2010 : 61). Penelitian ini menggunakan dua variabel, yaitu:

c. Variabel Dependen atau terikat Variabel dependen adalah variabel yang menjadi pusat perhatian utama peneliti. Hakekat sebuah masalah mudah terlihat dengan mengenali berbagai variabel dependen yang digunakan dalam sebuah model. Variabilitis dari atau atas faktor inilah yang berusaha untuk dijelaskan oleh seorang peneliti (Ferdinand, 
2006:26). Variabel dependen dinotasikan dengan Y. Dalam penelitian ini yang menjadi variabel dependen adalah keputusan pemilihan.

d. Variabel Independen atau bebas

Variabel independen merupakan variabel bebas yang dapat mempengaruhi variabel dependen (terikat) baik yang berpengaruh positif maupun yang berpengaruh negatif (Ferdinand, 2006:26). Variabel independen dinotasikan

\section{PEMBAHASAN}

\section{Hasil Analisa Regresi Berganda}

Dari hasil pengolahan data penelitian dengan menggunakan SPSS versi 17 for windows di peroleh hasil sebagai berikut dengan $X$. Variabel independen dalam penelitian ini adalah :

d. Harga $\quad\left(\mathrm{X}_{1}\right)$

e. Brand image $\quad\left(\mathrm{X}_{2}\right)$

f. Promosi $\left(\mathrm{X}_{3}\right)$ 
Hasil Analisa Regresi Berganda

Coefficients $^{\mathrm{a}}$

Hasil Analisa Regresi Berganda

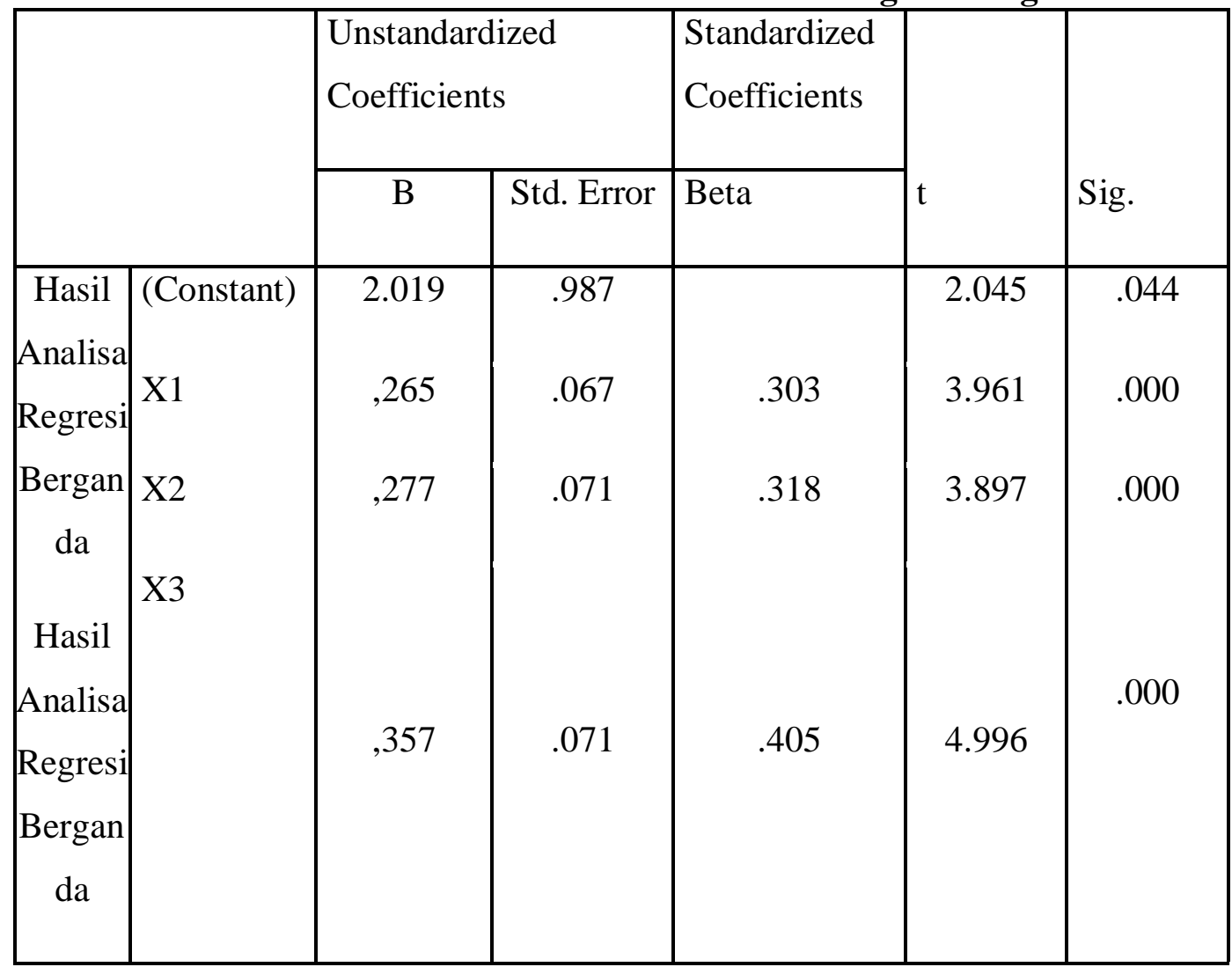

Dari rumusan analisa regresi berganda dengan rumus :

$\mathrm{Y}=\mathrm{a}+\beta_{1} \mathrm{X}_{1}+\beta_{2} \mathrm{X}_{2}+\beta_{3} \mathrm{X}_{3}+\mathrm{e}_{1}$

Keterangan :

$\mathrm{Y}=$ Permintaan

$\beta_{1}=$ Koefisien regresi dari promosi

$\beta_{2}=$ Koefisien regresi dari brand image

$\beta_{3}=$ Koefisien regresi dari harga

$\mathrm{X}_{1}=$ Promosi

$\mathrm{X}_{2}=$ Brand image

$\mathrm{X}_{3}=$ Harga

$\mathrm{a}=$ Konstanta

$\mathrm{e}=$ Error term

Diperoleh hasil : 
$\mathrm{Y}=2,019+0,265 \mathrm{X}_{1}+0,277 \mathrm{X}_{2}+$ $0,357 \mathrm{X}_{3}$

Interprestasi dari persamaan regresi linier berganda di atas adalah sebagai berikut :

1. $\alpha=2,019$ artinya jika promosi, brand image dan harga konstans maka permintaan telepon seluler berbasis smartphone di Gori 1 Cell Bojonegoro akan negatif.

2. $\beta_{1}=0,265$ menunjukkan bahwa promosi berpengaruh positif terhadap permintaan telepon seluler berbasis smartphone, artinya apabila promosi meningkat 1 akan meningkatkan keputusan pembelian telepon seluler berbasis smartphone di Gori 1 Cell Bojonegoro sebesar 0,265 dengan asumsi variabel brand image dan harga tetap.

3. $\beta_{2}=0,277$ menunjukkan bahwa brand image berpengaruh positif terhadap permintaan telepon seluler berbasis smartphone, artinya apabila brand image meningkat 1 akan meningkatkan keputusan pembelian telepon seluler berbasis smartphone di Gori 1 Cell Bojonegoro sebesar 0,277 dengan asumsi variabel promosi dan harga tetap.

4. $\beta_{3}=0,357$ menunjukkan bahwa harga berpengaruh positif terhadap permintaan telepon seluler berbasis smartphone, artinya apabila hargameningkat 1 akan meningkatkan permintaan telepon seluler berbasis smartphone di Gori 1 Cell Bojonegoro sebesar 0,357 dengan asumsi variabel promosi dan brand image tetap.

5. Nilai koefisien regresi harga memiliki koefisien regresi paling besar di antara variabel yang lain artinya harga merupakan variabel dominan dalam penelitian ini.

\section{Hasil Uji t}

Hasil uji t dari penelitian pengaruh promosi, brand image, dan harga terhadap permintaan telepon seluler berbasis smartphone di Gori 1 Cell Bojonegoro dapat di lihat dari tabel berikut : 
Tabel 4.9 Hasil Uji t

Coefficients $^{\mathbf{a}}$

\begin{tabular}{|c|c|c|c|c|}
\hline \multicolumn{2}{|r|}{ Model } & $\mathrm{T}$ & $\mathrm{t}$ tabel & Sig. \\
\hline & Promosi & 3.961 & 1.990 & .000 \\
\hline D & Brand Image & 3.897 & 1.990 & .000 \\
\hline $\begin{array}{l}\mathrm{p} \\
\mathrm{e}\end{array}$ & Harga & 4.996 & 1.990 & .000 \\
\hline $\mathrm{n}$ & & & & \\
\hline
\end{tabular}

VariabEL : permintaan

Berdasarkan tabel diatas membuktikan 1,990 ) dan taraf signifikansi $0,000<$ bahwa :

1. Promosi $\left(\mathrm{X}_{1}\right)$ mempunyai nilai $\mathrm{t}_{\text {hitung }}=3,961$ dan taraf signifikansi sebesar 0,000, berdasarkan data tersebut maka $\mathrm{H}_{0}$ di tolak, karena $t_{\text {hitung }}$ lebih besar dari tabel $(3,961>1,990)$ dan taraf signifikansi $0,000<0,05$. Hal ini juga berarti promosi $\left(\mathrm{X}_{1}\right)$ berpengaruh positif dan signifikan terhadap permintaan telepon seluler berbasis smartphone (Y). Kesimpulan dari pengujian ini $\mathrm{H}_{1}$ (hipotesis 1) diterima dan $\mathrm{H}_{0}$ di tolak.

2. Brand image $\left(\mathrm{X}_{2}\right)$ mempunyai nilai $t_{\text {hitung }}=3,897$ dan taraf signifikansi sebesar 0,001, berdasarkan data tersebut maka $\mathrm{H}_{0}$ di tolak, karena $t_{\text {hitung }}$ lebih besar dari $t_{\text {tabel }}(3,897>$ 0,05 . Hal ini juga berarti brand image ( $\mathrm{X}_{2}$ ) berpengaruh positif dan signifikan terhadap permintaan telepon seluler berbasis smartphone (Y). Kesimpulan dari pengujian ini $\mathrm{H}_{2}$ (hipotesis 2) diterima dan $\mathrm{H}_{0}$ di tolak.

3. Harga $\left(\mathrm{X}_{3}\right)$ mempunyai nilai $\mathrm{t}_{\text {hitung }}=4,996$ dan taraf signifikansi sebesar 0,000, berdasarkan data tersebut maka $\mathrm{H}_{0}$ di tolak, karena $t_{\text {hitung }}$ lebih besar dari $t_{\text {tabel }}(4,996>1,990)$ dan taraf signifikansi $0,000<0,05$. Hal ini juga berarti harga $\left(\mathrm{X}_{3}\right)$ berpengaruh positif dan signifikan terhadap permintaan telepon seluler berbasis smartphone (Y). Kesimpulan dari pengujian ini $\mathrm{H}_{3}$ (hipotesa 3) diterima dan $\mathrm{H}_{0}$ di tolak

4. . 


\section{Hasil uji F}

Hasil uji F disajikan dalam tabel 4.3 sebagai berikut :

Tabel 4.10 Hasil uji F

ANOVAa

\begin{tabular}{|ll|l|l|l|l|l|}
\hline \multicolumn{2}{|l|}{ Model } & $\begin{array}{l}\text { Sum } \\
\text { Squares }\end{array}$ & Df & Mean Square & F & Sig. \\
\hline $1 \quad$ Regression & 116.515 & 3 & 38.838 & 42.244 & $.000^{\mathrm{a}}$ \\
& Residual & 69.873 & 76 & .919 & & \\
& Total & 186.387 & 79 & & & \\
\hline
\end{tabular}

a. Dependent Variable: Y

b. Predictors: (Constant), Harga, Promosi, Brand image

\subsubsection{Hasil Koefisien Determinasi $\left(\mathbf{R}^{2}\right)$}

Hasil uji koefisien determinasi $\left(\mathrm{R}^{2}\right)$ disajikan dalam tabel 4.4 sebagai berikut :

Tabel 4.11 Hasil Uji Koefisien Determinasi $\left(\mathrm{R}^{2}\right)$

\section{Model Summary}

\begin{tabular}{|l|l|l|l|l|l|}
\hline Model & $\mathrm{R}$ & R Square & $\begin{array}{l}\text { Adjusted } \\
\text { Square }\end{array}$ & $\begin{array}{l}\text { Std. Error of } \\
\text { the Estimate }\end{array}$ & $\begin{array}{l}\text { Durbin- } \\
\text { Watson }\end{array}$ \\
\hline 1 &, $426^{\mathrm{a}}$ &, 181 &, 149 & 1,124 & 1,993 \\
\hline
\end{tabular}

a. Predictors: (Constant), Harga, Promosi, Brand image

b. Dependent Variable: Permintaan 


\section{KESIMPULAN DAN SARAN}

\section{Kesimpulan}

Dalam sub bab ini akan dipaparkan secara singkat mengenai hasil penelitian. Berdasarkan hasil analisa data, maka dapat diambil kesimpulan sebagai berikut :

1. Variabel Promosi, Brand image, dan Harga berpengaruh secara simultan terhadap permintaan telepon seluler berbasis smartphone di Gori cell Bojonegoro

2. Pengaruh variabel Promosi, Brand image, dan Harga terhadap permintaan telepon seluler berbasis smartphone di Gori cell Bojonegoro :

a. Variabel promosi berpengaruh terhadap permintaan telepon seluler berbasis smartphone di Gori cell Bojonegoro. Besarnya pengaruh variabel promosi yaitu 0.303 , artinya permintaan telepon seluler berbasis smartphone di Gori cell Bojonegoro ditentukan oleh variabel promosi sebesar $30 \%$.

b. Variabel brand image berpengaruh terhadap permintaan

\section{Saran}

a) Kepada Vendor Handphone

Berdasarkan penelitian yang dilakukan, variabel harga

memiliki pengaruh yang paling kuat terhadap permintaan telepon seluler berbasis

d. Variabel yang memiliki pengaruh paling dominan terhadap permintaan telepon seluler berbasis smartphone di Gori cell Bojonegoro adalah variabel harga.

Gori cell Bojonegoro. Besarnya pengaruh variabel brand image yaitu 0.318, artinya permintaan telepon seluler berbasis smartphone di Gori cell Bojonegoro ditentukan oleh variabel brand image sebesar $31,8 \%$.

c. Variabel harga berpengaruh terhadap permintaan telepon seluler berbasis smartphone di Gori cell Bojonegoro. Besarnya pengaruh variabel harga yaitu 0.405, artinya permintaan telepon seluler berbasis smartphone di Gori cell Bojonegoro oleh variabel harga sebesar $40,5 \%$. 
smartphone. Untuk itu, para

vendor handphone harus bisa menetapkan harga telepon seluler dengan tepat sehingga tidak merugikan bagi vendor dan juga tidak terlalu tinggi bagi pengguna telepon seluler.

b) Kepada Masyarakat

Untuk masyarakat agar tidak selalu berpedoman terhadap harga, belum tentu harga rendah memiliki kualitas bagus. Kualitas bagus biasanya sesuai dengan harga yang harus di bayar oleh para pengguna. Namun juga perlu diingat, membeli telepon seluler apalagi berbasis smartphone harus melihat dari berbagai aspek, bukan hanya dari aspek harga saja.

c) Kepada peneliti selanjutnya

$$
\text { Pada penelitian }
$$
mendatang, disarankan untuk menambah variabel independen yang digunakan yang tentunya dapat memberikan pengaruh terhadap permintaan telepon seluler berbasis smartphone. Dengan maksud agar dapat menghasilkan gambaran yang lebih luas mengenai permasalahan yang sedang terjadi . 


\section{DAFTAR PUSTAKA}

Alma, Dr. H. Buchari, 2013. Manajemen Pemasaran dan Pemasaran Jasa. Cetakan ke - 10. Bandung : Alfabeta

Dwintha, Ririn Triyani, 2012. Analisis

Bauran Promosi Dalam Meningkatkan Volume Penjualan Mobil Daihatshu ( Studi kasus PT. Jujur Sakti Makasar )

Fandy Tjiptono, 2014. Manajemen Pelayanan Jasa. Yogyakarta : Andi

Freddy Rangkuti, 2009. Strategi Promosi Yang Kreatif, edisi pertama, cetakan pertama. Jakarta : Gramedia Pustaka Utama

Hermawan Kartajaya, 2009.Mark Plus Basies. Jakarta : Erlangga http://xerma.blogspot.co.id/2013/08/pe ngertian-volumepenjualan.html

http://irwansahaja.blogspot.co.id/2014/ 05/volume-tujuan-dan-faktoryang.html

Kotler, Philip, keller, Kevin Lane, 2009. Manajemen

Pemasaran, Jilid I, edisi 13. Jakarta : Erlangga

Kotler, Philip, keller, Kevin Lane, $2009 . \quad$ Manajemen Pemasaran, Jilid II, edisi 13. Jakarta : Erlangga

Sugiyono, 2011. Metode Penelitian Kuantitatif Kualitatif dan R\&D. Bandung : Alfabeta

Sugiyono, 2013.Statistika Untuk Penelitian.Cetakan ke 22.Bandung : Alfabeta

Sumarni, Suprihanto, 2014. Pengantar Bisnis. Yogyakarta : LIBERTY

Alma, Dr. H. Buchari, 2013. Manajemen Pemasaran dan Pemasaran Jasa. Cetakan ke - 10. Bandung : Alfabeta

Dwintha, Ririn Triyani, 2012. Analisis

Bauran Promosi Dalam Meningkatkan Volume
Penjualan Mobil Daihatshu ( Studi kasus PT. Jujur Sakti Makasar )

Fandy Tjiptono, 2014. Manajemen Pelayanan Jasa. Yogyakarta : Andi

Freddy Rangkuti, 2009. Strategi Promosi Yang Kreatif, edisi pertama, cetakan pertama. Jakarta : Gramedia Pustaka Utama

Hermawan Kartajaya, 2009.Mark Plus Basies. Jakarta : Erlangga http://xerma.blogspot.co.id/2013/08/pe ngertian-volumepenjualan.html

http://irwansahaja.blogspot.co.id/2014/ 05/volume-tujuan-dan-faktoryang.html

Kotler, Philip, keller, Kevin Lane, $2009 . \quad$ Manajemen Pemasaran, Jilid I, edisi 13. Jakarta : Erlangga

Kotler, Philip, keller, Kevin Lane, 2009.

Manajemen

Pemasaran, Jilid II, edisi 13. Jakarta : Erlangga

Sugiyono, 2011. Metode Penelitian Kuantitatif Kualitatif dan R\&D. Bandung : Alfabeta

Sugiyono, 2013.Statistika Untuk Penelitian.Cetakan ke 22.Bandung : Alfabeta

Sumarni, Suprihanto, 2014. Pengantar Bisnis. Yogyakarta : LIBERTY 